Research Report No. 34/2008

\title{
Effectuating Public International Law Through Market Mechanisms?
}

Anne van Aaken

Follow this and additional works at: http://digitalcommons.osgoode.yorku.ca/clpe

\section{Recommended Citation}

van Aaken, Anne, "Effectuating Public International Law Through Market Mechanisms?" (2008). Comparative Research in Law \& Political Economy. Research Paper No. 34/2008.

http://digitalcommons.osgoode.yorku.ca/clpe/195 


\section{IP Comparative Research in Law \& Political Economy}

\section{Anne van Aaken}

Effectuating Public International Law Through Market Mechanisms?

EDITORS: Peer Zumbansen (Osgoode Hall Law School, Toronto, Director, Comparative Research in Law and Political Economy, York University), John W. Cioffi (University of California at Riverside), Lindsay Krauss (Osgoode Hall Law School, Toronto, Production Editor) 


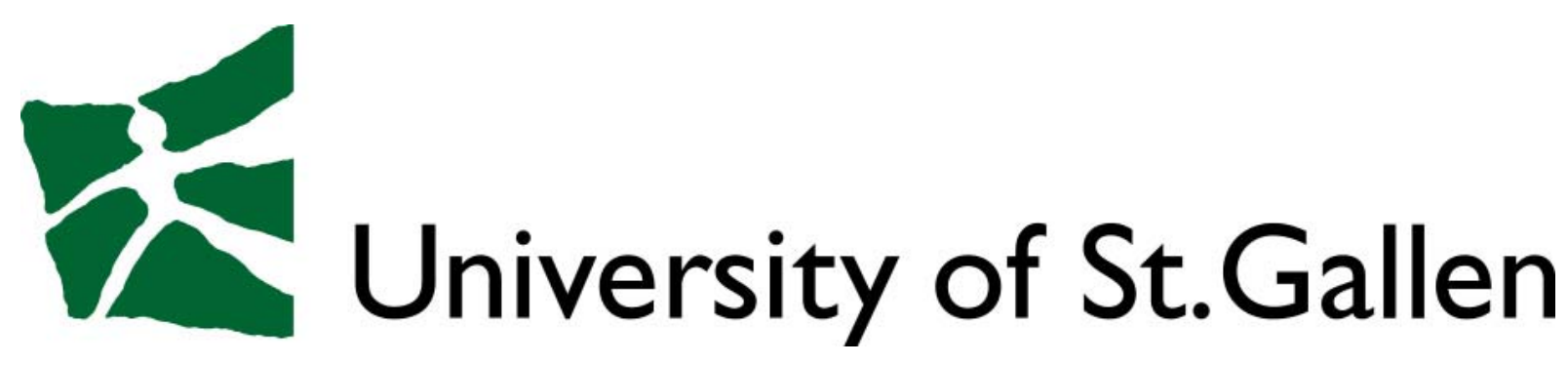

\section{University of St. Gallen Law School Law and Economics Research Paper Series}

Working Paper No. 2008-21

Sept 2008

Effectuating Public International Law Through Market Mechanisms?

Anne van Aaken

Published in:

Journal of Institutional and Theoretical Economics (JITE), 165(1), 33-57.

This paper can be downloaded without charge from the Social Science Research Network 


\title{
Effectuating Public International Law through Market Mechanisms?
}

by

\begin{abstract}
ANNE VAN AAKEN*
Traditionally, the enforcement of public international law (PIL) was a task of states: its addressees and its enforcers were states. That has changed recently. Whereas the influence of private market actors on the making of PIL has been extensively analyzed, their influence on its enforcement has been neglected, although the idea of using private interests in order to foster social goals has a long history. This article draws on theoretical insights of a rational-choice approach to PIL in order to analyze the prerequisites of effectuating PIL through privatemarket-actor incentives and market mechanisms. (JEL: K 33, F 55, F 59)
\end{abstract}

\section{Introduction}

Traditionally, the enforcement of public international law (PIL) was a task of states: both the addressees and the enforcers of PIL were states. The effectuation of PIL therefore depended on states, and the state could be treated as a black box. That has changed during the last decades. Ever more, PIL not only is addressing (ultimately) private persons or entities, but also is enforced through cooperation between states and nonstate actors (NSAs), ${ }^{1}$ be they enterprises or nongovernmental organizations (NGOs). The idea of making use of private interests in order to foster social goals has a long history and has been well acknowledged since Adam Smith. Also, the idea of using private interests for the effectuation of national law is also well known, certainly in private law, ${ }^{2}$ but also in international human-rights law and international investment law. This adjudicatory mechanism for the effectuation of law is used when private actors are the protégées of PIL, and it works through private individuals using litigation to effectuate their interests.

International legal scholarship, like national legal scholarship, has mainly relied on litigation and coercive mechanisms for making law effective. Within the

\footnotetext{
* I would like to thank Stefan Voigt and Rekha Oleschak for helpful comments, and also the participants in the Lübbenau Conference "Coordination in the Absence of Sovereignty" for very helpful comments. Special thanks go to Christoph Engel, Richard McAdams, and Peer Zumbansen.

${ }^{1}$ In the definition of this term, international organizations are not included.

${ }^{2}$ Early on, JHERING [1880].
} 
national realm, this is certainly justified - the coercive monopoly of the state as well as judicial mechanisms and state-backed enforcement of the law render other mechanisms of effectuating the law less important. In PIL, relying on coercive mechanisms like adjudicatory mechanisms and enforcement judicial decisions is much more problematic, first because not all issue areas of PIL have adjudicatory mechanisms, and second because the system lacks a central enforcement mechanism. Some commentators therefore even go as far as to deny the legal character of international law, calling it rather a system for cloaking power plays in legal terms. Other, more positivistic scholars just think of it as a de lege lata imperfect legal system and put much emphasis on describing it as a constitutionalized system in the making. ${ }^{3}$

But are there other mechanisms that could make international law effective? I submit that international legal scholarship has largely overlooked private market actors as enforcers as well as (self-enforcing) market mechanisms that might serve that purpose under certain circumstances to be identified. At the same time, I submit that, although NSAs and their role in effectuating international law have been analyzed, primarily by focusing on NGOs and their monitoring functions, private market actors have been neglected in the analysis - certainly as actors who are able to contribute to the effectuation of PIL. It is by no means my intention to deny the importance of national and international courts and tribunals and their contribution to the effectiveness of PIL. Rather, I would like to describe additional mechanisms that, in my view, have been neglected, thereby depriving PIL scholarship of one additional potential institutional mechanism for institutional design in the international sphere. In order to make my argument plausible, I will draw on several examples, which all describe different constellations in international law where market actors play a role for effectuating the regime.

Let me clarify what this paper is not: it is not a normative analysis and is not proposing any optimal mix of enforcement of PIL. Rather, it seeks to highlight certain mechanisms descriptively. It does not talk about the creation of market mechanisms (e.g., tradable emission certificates as in international environmental law), but seeks to highlight how existing markets are used for effectuating PIL. It also does not talk about NGOs as actors relevant to the effectuation of PIL (in the litigation or the enforcement stage), although their importance is by no means denied. Rather, I would like to highlight some mechanisms at work in fields hitherto not in the focus of research. This paper thus aims at making a contribution to the problem of effectiveness ${ }^{4}$ of international law, focusing on the role of private market actors and market mechanisms.

From an economic point of view, law matters to the extent that a marginal increase in compliance is generated (GUZMAN [2008, p. 23]). I understand the notion of effectuation broadly here: it includes all moments and modes in the compliance game, including the gathering of information on (non)compliance of

3 Peters [2006], Fassbender [1998], Walter [2001], Wet [2006], Frowein [2000], BOGDANDY [2006].

${ }^{4}$ Effectiveness and compliance are different notions. Whereas effectiveness looks for a causal mechanism between the law and the behavior - that is, law affects state behavior - compliance just looks at whether the behavior conforms to the norm. 
states, the way to litigation, the way judicial awards are enforced, and other situations where no litigation is available and self-enforcing mechanisms are used for effectuation.

The article is organized as follows. First, I will outline the underlying theory of this approach. I therefore draw on rational-choice international relations theory as well as an economic approach to international law (section 2). Then I will take up several constellations in international law to illustrate the relevance of the market mechanisms and market players for the effectuation of international law. By using those examples, I wish to highlight the diversity of, and simultaneously identify, common underlying prerequisites for the functioning of the market mechanism as a means of effectuating PIL (section 3). The last section summarizes and concludes (section 4).

\section{A Theoretical Approach to the Market as Enforcement Mechanism of International Law}

Much research has been conducted on the question of why certain PIL rules (hard or soft) come about, that is, PIL is used as explanandum. ${ }^{5}$ If law is taken as the dependent variable, many explanatory factors for the making of PIL can be taken into account. If, e.g., one wants to explain why there is harmonization of capital market regulatory standards, then the relative importance of market incentives, political pressure on the national plane, and multilateral institutions can be analyzed. ${ }^{6}$ The influence of NSAs - be they NGOs or private market actors - on the making of PIL, including soft law, in a two-level game played by governments in international negotiations ${ }^{7}$ (e.g., in trade or environmental law) is by now well established. Furthermore, the creation of private governance structures and joint initiatives on transnational rules, often initiated by NGOs together with business, sometimes also with the involvement of states, has been analyzed. ${ }^{8}$ Thereby, the first stage of the international-law game is analyzed.

My focus is different: I would like to take the effectiveness of PIL as explanandum, that is, I analyze the second stage of the game, when compliance decisions have to be made. Here, I wish to highlight a neglected variable in effectuating PIL: market forces and private market actors' incentives ${ }^{9}$ and their interplay with states in effectuating PIL. The black-box state is thus opened also in the compliance stage of the game. I am not submitting this approach as a

\footnotetext{
${ }^{5}$ See GoldSMith AND Posner [2005] and DobBin, SimmONS, AND GARRETT [2007] for the diffusion of national public policies.

${ }^{6}$ See SiMMONS [2001] for capital market standardization; see more generally GuZMAn [2008, pp. 119f.], AвBOTT et al. [2000], and ABBOTT AND SNIDAL [2000].

${ }^{7}$ Seminally, PUTNAM [1988]. See also LEVIT [2007].

${ }^{8}$ PATtBerg [2005] and references therein. See also Peer ZuMBAnSEN [2009], who highlights that many of the issues discussed are similar to those involved in privatepublic partnerships, hybrid forms of governance, and the idea of markets as regulators in the national sphere.

${ }^{9}$ Note that I am explicitly focusing on private market actors and not NGOs.
} 
panacea, and it cannot be expected to work in all areas of PIL (e.g., security), but it might work in many areas.

Two constellations can be distinguished: (1) private actors' interests are the object and purpose of the PIL norm; (2) private actors may be the ultimate addressees of PIL, but the object and purpose of the regulation is not their interest but a public good (e.g., trade, or fighting terrorism financing). In the first case, private actors usually have a right and therefore have a direct incentive to take up their own case, if PIL provides them with a legal possibility to do so, e.g., in international human-rights law and investment law. In the second case, the object and purpose of the treaties is not the protection of private market actors as such, but their interests are affected. Since there is no public-interest litigation in PIL, ${ }^{10}$ there is no direct legal avenue for them to make their interest heard in international adjudicatory mechanisms. But there are still two possibilities for using private market actors for the effectuation of PIL. In the case that international litigation for states is available, their role might be important in that they have a strong incentive to generate information on noncompliance of third states - information the governments usually do not have - and they may also pressure their governments to take action on the international plane, thereby having potential to mitigate the second-order enforcement problem in PIL in the litigation stage. Furthermore, there are regulatory network externality constellations in which PIL norms can make use of market mechanisms. Even if the international norms are not economic in purpose, they might still rely on market forces and private incentives if the markets are structured in a certain way. By market mechanisms I mean that the price mechanism is directly involved in the incentives generated for private actors through making market transactions become more costly (or even prohibitively costly) if the norms are not adhered to. After briefly discussing the effectuation of PIL if the state is considered a unitary actor, I will turn to the two constellations alluded to above: litigation and market mechanisms.

\subsection{Explaining the Effectiveness of PIL through the Unitary Actor State}

Most of the schools in international relations theory using rational-choice theory, certainly the realist school as well as the institutionalist school, ${ }^{11}$ analyze state behavior in compliance matters by assuming the state to be a unitary actor. Also, scholars in international law and economics tend to view the state as a black box, usually for methodological reasons (GUZMAN [2008, pp. 18f.], GOLDSMITH AND POSNER [2005, pp. 3f.) - a view to which I subscribe in principle. Although the liberal school, especially Moravcik (MorAvCsIK [1997]) and Slaughter (SLAUGHTER [2004]), have undertaken to the state into its different components, focusing on informal networks of government officials engaged in transnational

\footnotetext{
${ }^{10}$ There are a few exceptions under some regional human-rights treaties that allow for altruistic NGO litigation; see for details VAN AAKEN [2005].

${ }^{11}$ It is impossible to draw a more differentiated picture of the different schools in international-relations theory here. For an overview, see the articles in CARLSNAES, RISSE, AND SIMMONS [2002].
} 
governance, the role of market actors and forces in compliance matters has not received particular attention to date.

The focus of all schools is the explanation of how international law works (or does not work) and under what circumstances. In trying to explain how PIL is "able to affect state behavior despite a lack of coercive enforcement mechanism" (GUZMAN [2008, p. 9]), the view is broadened from the classical sources of PIL (treaties, custom, general principles ${ }^{12}$ ) to the inclusion of soft law, since all those norms are deemed to operate through the same basic set of mechanisms (GUZMAN [2008, p. 9]). This broad definition of PIL will be followed here. ${ }^{13}$

As a starting point for the theoretical discussion on effectiveness, the classical state-as-a-black-box view is briefly described. This allows us to investigate later in which constellations the role of private actors may be important. Depending on the underlying game-theoretical structure, compliance and effectiveness are either increased or decreased. In pure coordination games, no player has an incentive to defect from a given PIL norm. Once a standard is set, states are better off complying with the standard, e.g., in aviation security. It therefore should not matter whether there is law or just a social norm creating a focal point on which to coordinate. In mixed-motive games, e.g., a pure prisoners' dilemma (PD), the incentives to defect are far stronger. Each state has an incentive to defect, and even in a repeated game, compliance is by no means assured. Many games in between - especially the stag-hunt game, which is a trust game, as well as the battle-of-the-sexes game, which is a game of distributional concerns - have been analyzed by scholars in international law and economics. In pure coordination games, in common-interest games, and in the battle-of-the-sexes game, special arrangements for enforcing the law with sanctions are not necessary, as cooperation is the best strategy. Social norms, creating a focal point, are therefore sufficient. ${ }^{14}$ Cooperation is more difficult in a PD game, and frequent violations of the law are to be expected. Those analyses are not repeated here in detail. ${ }^{15}$

Why do we see compliance with international law nevertheless? Guzman develops a theory of compliance based on reciprocity, retaliation, and reputation, with a focus on the last (GUZMAN [2008, pp. 9, 33f.]). Usually, direct and indirect sanctions are distinguished. Direct sanctions are those that directly create costs for the violating states, e.g., war, retorsions, or reprisals. Indirect sanctions work through reputational mechanisms and deteriorate the violating state's ability to cooperate in the international sphere through its declining reputation for credible commitment. Direct sanctions include reciprocal noncompliance and retaliation. In the first case, the reciprocal action is not necessarily costly to the sanctioning state (apart from forgone gains from future cooperation); rather it results from a desire to maximize the payoff in the light of new circumstances. Defection of one party can thus be expected to lead to noncooperation by the other party in the

\footnotetext{
${ }^{12}$ See Art. 38 Statute of the International Court of Justice (ICJ Statute).

${ }^{13}$ Clearly, this is an external point of view on the law - a social-science perspective. This allows for the inclusion of nonbinding soft law in the definition of PIL, although it is not a source of law in the sense of Art. 38 ICJ Statute.

${ }^{14}$ On the role of focal points in compliance, see MCADAMS AND NADLER [2008].

${ }^{15}$ See GUZMAN [2008, pp. 33f.]; GOLDSMITH AND POSNER [2005].
} 
future. Noncompliance is thus only to be expected if a one-time defection yields bigger payoffs than continued cooperation. Reciprocity, though, works only where the benefits of an international agreement are excludable.

Retaliatory sanctions are costly to the sanctioning state and are intended to punish the violating state. Those sanctions can be political, economic, or even military. As is well known in PIL, sanctioning by retaliation thus leads to a second-order enforcement problem, as every state would prefer to free-ride and have other states bear the cost of retaliation (second-order PD). Thus, such sanctions are not imposed very often. But that may turn out to be correct only if one does not take into account the private actors involved, that is, if one does not play also a two-level game in enforcement.

Reputation is viewed by many rational-choice scholars (next to reciprocity (PARISI AND GHEI [2003]) and retaliation) as one of the main driving forces for compliance of states with PIL. ${ }^{16}$ If the assumption is correct that a state's reputation for poor compliance inhibits other states from cooperating with that state, noncompliance generates reputation costs as indirect sanctions for the future. This may change the payoff in a given game in a way that generates compliance. ${ }^{17}$ Nonreputational payoffs as well as reputational payoffs thus have to be taken into account in a theory of compliance. Reputational sanctions, though, can only work if there is information available on whether a state has complied or not. This is often difficult to obtain. Furthermore, there is uncertainty about the payoffs (by the violating state as well as all the other states); uncertainty about legal rules, especially if they are ambiguous or incomplete; and uncertainty about actions. International courts and tribunals have, i.a., the function of reducing those kinds of uncertainty - they have a fact-finding as well as a law-finding function. Court decisions are thus one way of making the reputational sanctions effective. Others are of course available, such as treaty-internal monitoring mechanisms, especially if outcomes are made transparent to other states and/or the public. Also in those constellations, private actors might be important in order to initiate litigation.

\subsection{Explaining Effectiveness through Private Market Actors' Incentives}

How can private market actors contribute to the compliance of states, and in particular to the reputational mechanism? And are there further mechanisms to generate compliance? In my view, yes, once we open the black-box state and look at private actors incentives in litigation and market mechanisms as two possible constellations. That leads me to the point I would like to make in this paper: A theory of compliance with PIL should not be confined to state behavior only. Rather it should be complemented by the role of private market actors in effectuating PIL. Those constellations come in two forms: In the first, litigation is involved, and private market actors' incentives to litigate are used to effectuate international law. This form has been often analyzed in the areas of trade,

\footnotetext{
${ }^{16}$ GUZMAN [2002], [2008], DowNS AND JONEs [2002]. Differently, GOLDSMITH AND POSNER [2005] attribute little behavioral force to reputation.

${ }^{17}$ Extensively in GUZMAN [2008, pp. 34-41] as well as GUZMAN [2002].
} 
investment, and human rights. ${ }^{18}$ In the second form, there are no adjudicatory mechanisms and thus no litigation, but PIL is designed so that it is in the interest of market actors to adhere to the law. Here, states alone would not be able to effectuate PIL, nor would private parties; but their interplay might lead to compliance with PIL. Both of these forms will be analyzed below.

\subsubsection{Enhancing Effectiveness through Litigation}

In many constellations, PIL's ultimate addressees are private persons and market actors. They may influence the effectuation of PIL in three ways: private litigation on the international level based on PIL, private litigation on the national level based on PIL, and fostering international litigation in state-to-state disputes. The last way will be illuminated in Section 3 of this article by an example; the first two ways are self-evident and have been extensively analyzed.

In the first way, private actors have a direct interest in making the states adhere to the law, because their interests are directly protected by the PIL norm. Sometimes, there is also a direct course of action for individuals or businesses to hold their own state or third states accountable under PIL through international adjudicatory mechanisms. If what the international norm protects is not a direct interest of a state but rather rights of private persons, litigation by states is less likely to be used if only state-to-state litigation is available. Governments act as a "political filter" (SYKES [2005, pp. 647f.]). A state would weigh all other interests (e.g., foreign policy concerns) against the interest of taking up a case against another state before international tribunals; in contrast, if private persons have the legal possibility to bring claims, no such considerations interfere. Evidently, if an actor is not directly affected by a state measure, the incentive to bring a complaint is not high; the same applies to states, e.g., for inter omnes norms (second-order PD). All human-rights treaties allow for interstate complaints, and in all such treaties interstate complaints are greatly underutilized in comparison with private actions. ${ }^{19}$ Thus, Scott and Stephan consider the ability of private persons to initiate proceedings directly as one hallmark of the "formal enforcement" of $\mathrm{PIL}^{20}$ since directly affected persons are much more likely to take up their own case. International investment law, human-rights law, and European Union law are the foremost examples where private actors have an interest of making their own (or third) states comply with the law and are given a private right of action. This holds true especially if the costs for using the system are minimized. Equally, European Union law can be said to be effectuated not only through the direct effect (which leads to an enforcement of EU law on the national plane), but also in that private actors have, under certain circumstances, direct or indirect access to the European Court of Justice. ${ }^{21}$ Here, private (market) actors have a double function: they generate information on noncompliance of states, and they initiate

\footnotetext{
${ }^{18}$ For trade law, see SYKES [2005]; for human rights, see VAN AAKEN [2005]. For investment law the mechanism is obviously private enforcement; see for an overview DOLZER AND SCHREUER [2008].

${ }^{19}$ For details see VAN AAKEN [2005].

${ }^{20}$ SCOTT AND STEPHAN [2006]; also GUZMAN [2008, p. 50].

${ }^{21}$ See the articles in BAUDENBACHER AND BUSEK (eds.) [2008].
} 
litigation, thus circumventing the gatekeeping function of diplomatic protection. Nevertheless, the possibility of direct action by private actors solves only the first step in the enforcement stage of the game. International judicial decisions are not necessarily complied with - the second-order enforcement problem still arises in the postlitigation compliance phase.

There is an issue area, though, where this problem is also mitigated through market forces: international investment law. Here, private actions against foreign states are very forceful, especially because there is usually no exhaustion-of-localremedies requirement. Thus the first stage of enforcement, bringing a complaint, directly relies on the incentive of a private market actor. Furthermore, also the second stage of enforcement, compliance with an international award, is fostered through private market actors. The decisions of the international tribunals on the payment of damages can be enforced in any other member state of the ICSID Convention $^{22}$ and are thus readily utilizable. Here, there is no second-order enforcement problem, as the private party is given, by means of decisions that are res judicata, an enforcement possibility in any other state, using the central enforcement mechanisms of national legal orders. If the ICSID is the venue chosen, then the case is well publicized, thus enhancing the force of reputational costs for states, as such disputes lead presumably to less foreign direct investment, since investors shun states with too high political risks. The market for capital may thus enhance compliance. One should note that the reputational factor does not relate to the future cooperation with other states, but to the future cooperation of private actors.

In the second form, private actors use national litigation to effectuate PIL. International legal scholars, as well as some international-relations scholars, rely to a large extent on the implementation of PIL in the national legal orders and thus the enforcement of PIL through national courts, which are deemed also to internalize PIL. ${ }^{23}$ The added value of this view is that it captures legal mechanisms of national commitment to international norms. It also illuminates the different ways in which PIL can be effectuated. The Human Rights Act of Great Britain of 1998, e.g., makes a difference for that country's adherence to the European Convention of Human Rights (ECHR), in that British citizens may now allege a violation of the ECHR directly in British courts. The direct effect of European Community Law in the national legal orders of member states is another prominent example. This kind of effectuation relies on the central enforcement mechanisms for national legal orders, once a decision is issued. But with very few exceptions, there is no direct effect of PIL in the national legal orders. For scholars in international law and economics, the interplay with national courts has not been at the forefront of discussion, in contrast with international-law scholars,

${ }^{22}$ Convention on the Settlement of Investment Disputes between States and the Nationals of Other States (ICSID Convention), Washington, DC, 18 March 1965, in force 14 October 1966, 575 United Nations Treaty Series 159.

${ }^{23} \mathrm{KOH}$ [1997b], [1997a], SLOSS AND JINKS (eds.) [2009]. Here, also tort litigation by private actors against private actors is relevant, as in connection with the United States Alien Tort Claim Act, whereby private individuals may sue other individuals or entities on the basis of Customary International Law. 
who stress that mechanism. Since this form relies on the central enforcement mechanism of nation-states, it will not be discussed further here.

In the third form, private market actors' interests are protected only indirectly. The more obvious role of private actors in those issue areas of PIL where they have a direct complaint mechanism at their disposal should not make us overlook the less obvious one: the role of private parties does not stop with the possibility of having direct access to international courts. Rather, they can also play a role in enforcing PIL when given domestic possibilities to force their states to take a case to the international plane. The inertia of the potential sanctioning state can be overcome through the impetus and push of private market actors who have an interest in the effectiveness of PIL, e.g., by lobbying their governments. ${ }^{24}$ This recourse is even stronger if states have committed themselves to listen to private actors by creating legal venues for them to make their government act. Legal procedures of this kind, especially if the decision of the government to take an action (or not) against another state is subject to judicial review, considerably cut the discretion of governments and thus mitigate the second-order enforcement problem. Once a case reaches the international realm (e.g., courts and tribunals), noncompliance will be readily observable and monitored, and reputational costs thus enhanced. Information is thus generated for other states to learn about noncompliance of other states. This can have an impact on the reputation of the violating state and thus change the payoff for violations. In the case of European Union law, there is another effective watchdog, namely the European Commission, which can take violating states to the European Court of Justice. This is, though, rather exceptional in PIL.

\subsubsection{Effectuation of International Law through Market Mechanisms}

A further, and in my view much less researched, area is the constellation where law is constructed in such a way that it is in the self-interest of rational market actors to adhere to international law: PIL can here be effectuated through market mechanisms. In many issue areas of PIL, there is no international adjudicatory mechanism and the ultimate addressees (although not the protégées) of the law are private actors. If the incentives for the private actors are such that they comply with the law, the law can become effective through being self-enforcing, if certain prerequisites are met. Here, the focus is not mainly on the governments' role in compliance with PIL, but rather on governance. If it is true that in ever more areas of PIL "we observe complex blends of private and public governance" (АВBOTT AND SNIDAL [2001, p. 346]), ${ }^{25}$ it makes sense to include in the analysis the role and incentives of private actors, especially the use of market mechanisms.

A good starting point for understanding in which constellations market mechanisms may work is the question of externalities. Externalities occur if one

\footnotetext{
${ }^{24}$ Of course, also NGOs may lobby their governments, but usually they have no legal venue to do so. Furthermore, they are not the focus of this paper.

25 ABBOTT AND SNIDAL [2001, p. 346]. Whereas they ask why governance arrangements are likely to emerge, I leave out the question of international law or standards as explanandum and focus instead on compliance, that is, under what conditions given governance arrangements are effective.
} 
actor's conduct affects the well-being of another without the other's agreement, or if the externality is not taken into account by the market mechanism (pecuniary externalities).

The theory of network externalities is especially helpful in our context. It has been developed for technical networks, like telephones and software. ${ }^{26}$ Here, individual benefits increase with the number of users through expanding markets, reduced incompatibilities, and economies of scale. All actors have an interest of using the technical standard; there is no incentive to defect. In addition to technical externalities, there are also regulatory externalities, coming about through standards set by international standard-setting bodies or by treaty law. In the phase of standard setting, that is, lawmaking, we are typically faced with a pure coordination game or a battle-of-the-sexes game, in the case where actors disagree on which standards should be chosen but still prefer a common standard. In those cases, compliance is secured once the standard is set. In a PD game, with traditional externalities, each actor might prefer to set his own standard. Yet, they also have an interest in setting a standard that is mutually beneficial for all. Once the standard or norm is set - that is, once we are in the compliance stage of the game - there may be an interest in complying with the standard if noncompliance is sanctioned severely enough. This depends on how the compliance system is set up. If, e.g., the system creates network externalities through introducing market sanctions for noncompliant members, ${ }^{27}$ then states or market participants have an interest in complying with the standard. If the sanction for noncompliance is the exclusion of the noncompliant member from the club or network, this can be very costly and induce compliance even in a PD game, but only if the exclusion costs are higher than the costs of defecting. If cheating is not detectable, there is still an incentive to defect. Thus, creating regulatory network externalities as an enforcement mechanism works under the assumption of low transaction costs, a sufficient amount of information, and the absence of collective action problems.

As noted above, the reciprocity compliance mechanisms work between states if the benefits derived from cooperation are excludable. Reciprocity can also play a role on the private market actors' level, if the market players can be excluded. This suggests that if the PIL regulation uses markets, then - even if public-good creation is the ultimate goal, as with preventing terrorism financing or mitigating civil wars through restricting trade in conflict diamonds - the chances that states and private actors will comply with the standards are augmented. A prerequisite for changing payoffs de facto (not only as black-letter law) and inducing compliance is therefore the possibility of excluding market players from a market (or considerably augmenting the costs of transactions with nonmembers). Thereby, a club good is created (see BuCHANAN [1965]). That will happen only if most of the market players are in the system and exclusion implies a bar to transacting or trading; that is usual for market players, and may be true, depending

\footnotetext{
${ }^{26}$ Seminally, KATZ AND SHAPIRO [1985], [1994], LIEBOWITZ AND MARGOLIS [1994], BESEN AND FARRELL [1994].

${ }^{27}$ But see generally, on the trade-off between tough compliance schemes and securing membership in PIL, HELFER [2008]. This applies to states, but not necessarily to markets, as the incentive to play within the market is very strong, if not a prerequisite to play at all.
} 
on the issue area, for states. It works only if the relevant markets are open to cross-border transactions.

Furthermore, a system for detecting noncompliance is necessary. Thus, some systems of monitoring, be it through NGOs or through peer-review mechanisms providing for transparency, are a prerequisite. Monitoring requires collective action by the participants to create the public good of adherence to the law. Here, of course, the exclusion may be costly to the excluders, and again a second-order enforcement problem may arise. There are three reasons why it may work nevertheless. First, the individual monitoring and reporting costs of the participants may be low if the information on defectors is generated in the market transaction itself. Second, we know from public-good experiments that actors under certain circumstances punish defectors even if it is costly to themselves (Ostrom [2000]). Third, the system may be set up in such a way that nonmonitoring or nonreporting itself is punished by exclusion from the club.

It should be noted that this approach is compatible with the managerial approach of Chayes and Handler Chayes, who view the primary causes of noncompliance as the limits of states' capacity to comply and the legal ambiguity of PIL (CHAYEs AND HANDler Chayes [1993]). The limits of state capacity can be mitigated if there are private actors actively involved in the effectuation of PIL. Oftentimes, states do not have the monitoring facilities to assure compliance with PIL. If private market actors have an active interest in reporting in order to punish free-riders, the state's capacity may be improved.

\section{Different Constellations of the Market as Enforcement Mechanism}

In order to illustrate the role of market mechanisms and private market players in the enforcement of PIL, I draw on several examples, exemplifying different constellations. I start with an international regime in the economic sphere that is based on treaty law and has an adjudicatory mechanism (the WTO), so that litigation is an effectuating factor but there is no direct venue for private market actors. I then turn to an international soft law regime, also in the economic sphere (the Financial Action Task Force). After that, a mixed regime will be analyzed, one where states, industry, and NGOs are all participating (the Kimberley Process).

\subsection{International Regimes with a Central Enforcement Mechanism: The Trade Regime}

The international trade regime, the WTO, might seem not to be a candidate for analysis here, as the WTO is seen as a rather effective state-to-state international treaty. ${ }^{28}$ Nevertheless, in the WTO system, the role of private actors in bringing complaints works indirectly through a bottom-up approach, and the incentive to comply with a decision of the Dispute Settlement Body (DSB) works again through market forces (hindering market access through retaliation). The other

\footnotetext{
${ }^{28}$ The implementation rate of WTO decisions is estimated to be $83 \%$ (BRONCKERS [2008, p. 121]).
} 
possible candidate for analysis, investment law, works through a direct possibility of complaint by private actors (thus the second-order enforcement problem is mitigated), and again the incentive to comply with an international arbitral decision is partly set by the market (the competition for capital). Investment law has been extensively dealt with and will not be discussed here. ${ }^{29}$ Rather, I will briefly describe a system less in the forefront of the debate in the context of compliance: that of the WTO law. WTO law has many ways to be effectuated apart from the formal complaint procedures at the DSB. It may have direct effect in some countries, allowing private parties to challenge WTO-inconsistent measures before national courts. Furthermore, national courts would - even if there is no direct effect - interpret national law in the light of the international trade obligations. ${ }^{30}$ Legislators routinely take trade obligations into account. Those means describe the effectuation of PIL in the national legal orders.

On the international plane, WTO law allows only for state-to-state complaints. Nevertheless, it is well known that the bulk of WTO disputes are triggered by private industries complaining about foreign measures. Most countries rely on informal complaint mechanisms for their industries; ${ }^{31}$ in Switzerland, e.g., the joke goes that one just picks up the phone to call the minister. In such countries, the government is free to take a case to the WTO or not; it has full discretion over its decision. Other countries have, however, introduced formal complaint procedures for their industries to have their governments bring a case to the WTO, namely, the United States, the European Union, and China. ${ }^{32}$ Those procedures are meant not only to encourage private market players; they are also a venue for gathering information on noncompliance of other states - a task a government would not be up to. ${ }^{33}$ Those procedures give a private course of complaint to affected industries or companies, pursuant to which the government's handling of private petitions about allegedly illegal foreign measures is subject to certain procedural guarantees. Usually, the government has a duty to investigate the case, it can require information from the complainants, and it consults and negotiates with the government of the violating state. In many cases, a solution is found bilaterally. The criteria on which a government can decline to take up a case are defined in the law, and, if the government does not take up the case, it may be subject to judicial review, as it is under the EC Trade Barriers Regulation. ${ }^{34}$ Nevertheless, the regulations always leave open a discretionary window allowing

\footnotetext{
${ }^{29}$ See, for a convincing rationale of why investment law gives a direct course of action to private parties and WTO law does not, SYKES [2005].

${ }^{30}$ For an overview of the role of WTO law in national legal order, see LESTER AND MERCURIO [2008, pp. 123-149], BRONCKERS [2008, p. 132].

${ }^{31}$ Unfortunately, there is no centralized information in the WTO Secretariat on which WTO member states have formal complaint procedures.

${ }^{32}$ See, more generally (including the U.S.), BRONCKERS [2008], SHAFFER [2003]; for the EC Trade Barriers Regulation (EC Council Regulation 3286/94, OJ 1994, L349/71) and its history, see BRONCKERS AND MCNELIS [2001]; for the EU and China, see SoNG [2007]. India has a venue for complaints, but does not formalize any procdures.

${ }^{33}$ For this line of thought, see MCCUBBINS AND SCHWARTZ [1984].

${ }^{34}$ Case T-317/02, FICF et al. v. Commission of the European Communities, O.J. C 45, February 19, 2005, p. 22.
} 
for the consideration whether an investigation is in the interest of the particular state. ${ }^{35}$ If the states in question are members of the WTO, the governments cannot take retaliatory sanctions unilaterally; rather, they have to use the WTO dispute settlement machinery. ${ }^{36}$

Although those procedures vary in their details, they all have one thing in common: they restrict the discretion of governments to bring a case to the WTO and give private market actors a formal way of expressing their grievances. From a public-choice point of view, interests of exporters in a country are strengthened in comparison with those of more protectionist importers. By this, the national players in the two-level game of enforcement are given more importance, and the enforcement system of WTO is strengthened.

The U.S. and the EU are the members that use the dispute system of the WTO most frequently. Since 1 January 1995, 369 disputes have been referred to the DSU. ${ }^{37}$ The EU had 78 cases as a complainant; the U.S., 89 cases. These numbers far exceed those of any other country, ${ }^{38}$ and may not be due to their trading power only (although an empirical study is still missing).

\subsection{International Soft Law Regimes without Litigation: The FATF}

A further interesting regime in which market mechanisms play an important role without litigation being available for its functioning is the Financial Task Force on Money Laundering (FATF). It is an intergovernmental body with the purpose of the developing and promoting national and international policies to combat money laundering and terrorist financing, which are viewed as destabilizing the international financial system. The FATF was created by a G-7 summit in Paris in 1989 and has 34 member countries. The FATF published 40 recommendations in the area of money laundering (ML) in 1990 (revised in 1996 and 2003) and added 9 recommendations after 9/11 on the topic of terrorism financing (TF). The aim of the FATF is, although its membership is not universal, to universalize the standards. The recommendations are to some extent identical with those of the UN Convention against Transnational Organized Crime (2000), the UN Convention against Illicit Traffic in Narcotic Drugs and Psychotropic Substances (1988), and the UN Convention for the Suppression of the Financing of Terrorism (1999), as well as Security Council measures that needed to be undertaken under the various antiterrorism resolutions after 9/11. ${ }^{39}$ Although they are nonbinding on the states (that is, they are international soft law), their implementation can be viewed as

${ }^{35}$ Art. 8.1. EC Council Regulation 3286/94; Art. 16, “Chinese Foreign Trade Barriers Investigation Rules,” available at www.lawinfochina.com. See also SoNG [2007, pp. 812f.].

${ }^{36}$ Therefore, Section 301 of the US Trade Act of 1974 was subject to a WTO complaint procedure; see United States - Sections 301-310 of the Trade Act of 1974, WTO Panel Report, WT/DS152/R, adopted January 27, 2000, paras. 7.38-7.39.

${ }^{37}$ WTO, WT/DS/OV/32 of 24 January 2008, ii.

${ }^{38}$ See WTO, “Disputes by Country,” available at http://www.wto.org/english/tratop_e/ dispu_e/dispu_by_country_e.htm.

${ }^{39}$ For an extensive comparison with the respective UN Conventions and resolutions as well as EU money-laundering directives, see VAN AAKEN [2004]. 
very effective. The 40 recommendations on ML contain primarily measures states have to take internally to ensure effective combat against $M L,{ }^{40}$ such as criminalizing ML and TF (Recommendation 1), legislative measures to enable their competent authorities to confiscate property laundered and proceeds from money laundering or predicate offences (Recommendation 3), and prescribing measures for financial institutions and other businesses ${ }^{41}$ to implement customer due diligence (CDD) and record-keeping to know their customers (KYC) (Recommendations 4, 5, 10), with an enhanced system for "politically exposed persons” (PEPs) (Recommendation 6). In interbank and cross-border transactions, the financial institution has to make sure that the corresponding institution adheres to the recommendations (Recommendation 7). This amounts to a market peerreview mechanism. The firms also have to report suspicious transactions and compliance (Recommendation 13 et seq.) to a national financial intelligence unit (Recommendation 26 et seq.). Most of the recommendations ultimately address private actors in the financial market industry.

Of interest for our topic are especially the monitoring and enforcement mechanisms. ${ }^{42}$ They consist in a self-assessment exercise and a mutual peerreview evaluation. In the self-assessment exercise, every member country provides information on the status of its implementation of the recommendations by responding each year to a standard questionnaire. The second element for monitoring the implementation is the mutual evaluation process, which is by now in its third round. Each member country is examined in turn by the FATF on the basis of an on-site visit conducted by a team of selected experts in the legal, financial, and law-enforcement fields from other member governments. The purpose of the visit is to draw up a report assessing the extent to which the evaluated country has moved forward in implementing an effective system to counter ML and to highlight areas in which further progress may still be required. The mutual evaluation process is enhanced by the FATF's policy for dealing with members not in compliance with the recommendations. The measures contained in this policy represent a graduated approach aimed at reinforcing peer pressure on member governments to take action to tighten their anti-money-laundering systems. The policy starts by requiring the country to deliver progress reports at plenary meetings. Further steps include a letter from by the FATF president or sending a high-level mission to the noncomplying member country. The FATF can also apply Recommendation 21, which results in issuing a statement calling on financial institutions to give special attention to business relations and transactions with persons, companies, and financial institutions domiciled in the noncomplying country. Then, as a final measure, the FATF membership of the country in question can be suspended.

\footnotetext{
${ }^{40}$ For the text, see http://www.fatf-gafi.org/document/28/ 0,3343,en_32250379_32236930_33658140_1_1_1_1,00.html\#Introduction.

${ }^{41}$ Casinos, dealers in precious metals and precious stones, lawyers, notaries, other independent legal professionals, and accountants when they prepare for or carry out certain transactions for their clients.

${ }^{42}$ See FATF [2008].
} 
Since the FATF aims at universal compliance with its standards, also nonmembers of the FATF are monitored, and since 1998 it has been possible to blacklist a nonmember as a so-called noncooperative country or territory (NCCT). ${ }^{43}$ The goal of this initiative has been to secure the adoption by all financial centers of international standards to prevent, detect, and punish ML and $\mathrm{TF}$, and thereby effectively cooperate internationally in the global fight against ML and TF. Forty-seven jurisdictions were referred to the NCCTs process and were reviewed in two rounds (31 in $2001^{44}$, and 16 in $2002^{45}$ ). A total of 23 jurisdictions were identified as NCCTs (15 in 2000, and 8 in 2001). The FATF recommended that financial institutions give special attention to transactions involving the NCCTs, in accordance with Recommendation 21. That basically implies that enhanced scrutiny is necessary when conducting business with companies or financial institutions from a NCCT, thereby augmenting transactions costs considerably for both parties. In addition to the application of Recommendation 21, in cases where NCCTs had failed to make adequate progress, the FATF recommended the application of further countermeasures taken in concert. These included the possibility of stringent requirements for identifying clients and enhancing advisories (including jurisdiction-specific financial advisories) to financial institutions for identification of the beneficial owners before business relationships are established with individuals or companies from these countries; enhanced relevant reporting mechanisms or systematic reporting of financial transactions on the basis that financial transactions with such countries are more likely to be suspicious; taking into account the fact that the relevant bank is from a NCCT when considering requests for approving the establishment in FATF member countries of subsidiaries or branches or representative offices of banks; and warning non-financial-sector businesses that conducting transactions with entities within the NCCTs might run the risk of money laundering (FATF [2007, p. 4]). As a means of last resort, it was foreseen that all financial transactions with NCCTs might be prohibited. In 2006, Myanmar, the last country on the blacklist, was delisted from it. Since then, no country has been blacklisted. Assuming that the influence of the FATF has not diminished, this can be called a success, though it has been heavily criticized for contravening international law by effectively threatening an economic embargo on NCCTs (see DoYLE [2002, p. 281]).

How can a soft law regime be so effective? First of all, the member countries of the FATF cover all the largest financial centers of the world and thus cover the major part of global financial transactions. One state alone (e.g., the United States) could not have achieved that, since other financial market centers could have profited from stricter regulation in the United States. A pure export of regulation would thus have been difficult. By involving all the big financial

${ }^{43}$ See for details FATF [2007] and STESSENS [2001].

${ }^{44}$ See FATF [2007, p. 2].

${ }^{45}$ Costa Rica, Czech Republic, Egypt, Grenada, Guatemala, Hungary, Indonesia, Myanmar, Nigeria, Palau, Poland, Slovakia, Turks \& Caicos Islands, United Arab Emirates, Ukraine, and Uruguay. (The eight jurisdictions identified as NCCTs at that time are in italics.) 
centers, this problem was mitigated. But the weakest-link problem could still appear, and thus the FATF sought to universalize the standards. They could do so because the club they formed was big enough to shut other states out of the global financial market. Secondly, the regime instituted a peer-review system with onsite inspections. Although there is no information on the internal processes of the countries that were blacklisted, it can be assumed that considerable internal pressure was exerted on governments by their financial (and nonfinancial) businesses, as their costs of doing business with the rest of the world (and the largest financial markets) were effectively augmented considerably. By targeting the financial market industry as the ultimate addressee of the measures, the FATF can use the regulatory network externalities as incentives to make states comply with the system. By effectively sanctioning the financial market sector in noncomplying states, the two-level game shifts the payoffs, leading to compliance. Also, nonmonitoring and nonreporting in this case lead to punishment by the other states and their banks. The collective-action problem in enforcement is thereby mitigated.

\subsection{Mixed Regimes without Litigation: Kimberley Process Certification Scheme}

Let us now turn to a phenomenon that has been widely noticed in the humanrights sphere: The Kimberley Process Certification Scheme (KPCS). Although it is still subject to criticism for ineffectiveness, ${ }^{46}$ it is nevertheless praised for its success for curbing the trade in conflict diamonds. ${ }^{47}$ It is one of the first regimes where states, industry, and NGOs not only have set the rules but also do the monitoring and enforcement of the regime. The Kimberley Process is not a treaty; it is nonbinding on its state parties and is not legally enforceable by an international tribunal. Yet, the measures taken by the parties to the agreement, including the diamond industry, show that it was intended to obligate its participants, that it is enforceable, and that, by the effects of its operation, it is de facto binding on all of its members (see CURTIS [2007], FELDMAN [2003]).

The system was developed at the beginning of this century when it became ever clearer - especially through NGO campaigning - that diamond exploration and trading is fueling civil wars and grave human-rights abuses in Africa, and contributing to some extent to the profits of the diamond industry (see TAMM [2004]). Although the United Nations had issued trade embargoes under Chapter VII of the UN Charter, requiring all states to comply with their provisions (Art. 103), for several African countries (Angola, Sierra Leone, Liberia), although the General Assembly had issued recommendations, ${ }^{48}$ the flow of conflict diamonds was not substantially curbed - they are difficult to trace to their origin, and they

46 Global Witness [2005]; Amnesty International [2006]; Partnership AFRICA CANADA [2006].

${ }^{47}$ Diamond experts estimate that conflict diamonds now represent a fraction of one percent of the international trade in diamonds, compared to estimates of up to $15 \%$ in the 1990s; see www.kimberleyprocess.com.

${ }^{48}$ See G.A. Res. 55/56, U.N. GAOR, 55th Sess., Agenda Item 175, U.N. Doc. A/RES/55/56 (2001); G.A. Res. 56/263, U.N. GAOR, 56th Sess., Agenda Item 37, U.N. A/RES/56/263 (2002), endorsing the Kimberley Process. 
are the most densely concentrated wealth of the world, which makes them easy and attractive to smuggle: they are highly valuable, small in size, easy to hide, and not detected by metal detectors. As international reactions by NGOs - and by consumers - became stronger, a first international meeting of Southern African diamond-producing states designed to combat the conflict-diamond trade was convened in the South African diamond town of Kimberley in May 2000. Later that year, in December, the UN General Assembly adopted a resolution supporting the creation of an international certification scheme for rough diamonds. ${ }^{49} \mathrm{By}$ November 2002, negotiations between governments, the international diamond industry, and civil-society organizations in Interlaken, Switzerland, resulted in the creation of the Kimberley Process Certification Scheme (KPCS). The Kimberley scheme was formally adopted on 5 November 2002 in the Interlaken Declaration ${ }^{50}$ and became effective on 1 January 2003, when participating countries started to implement its rules.

The KPCS document ${ }^{51}$ sets out the requirements for controlling rough-diamond production and trade. The Kimberley Process sets up an international scheme of certification requirement for rough-diamond exports to, and imports from, participants. Certification requires certain minimum standards and aims to eliminate conflict diamonds ${ }^{52}$ from all shipments to and from participants. Countries that do not participate in the KPCS are effectively shut out of the market, as its participants account for approximately $99.8 \%$ of the global production of rough diamonds. ${ }^{53}$ Participants have to ensure that no shipment of rough diamonds is imported from or exported to a nonparticipant (§ III (c) KPCS). Trade between Kimberley participants is restricted to certified nonconflict diamonds, and trade between Kimberley participants and nonparticipants is prohibited altogether (see PAUWELYN [2003, p. 1179]).

Participants - by now 48, representing 74 countries (with the European Community and its Member States counting as an individual participant) - have to implement national regulations with respect to the certification scheme, together with internal systems of controls. They have to meet the requirements of forgeryproof and tamperproof certificates and shipping containers for the transport of rough diamonds. Furthermore, they have to provide quantitative statistics on imports, exports, and mining activities. These minimum standards only apply to rough diamonds and import and export controls. States also have to maintain dissuasive and proportional penalties for transgressions. Beyond that, no additional requirements need be met. This flexible approach was also meant to make

\footnotetext{
${ }^{49}$ G.A. Res. 55/56, U.N. Doc. A/RES/55/56 (Dec. 1, 2000), para. 5, 6.

${ }^{50}$ Interlaken Declaration of November 2002 on the Kimberley Process Certification Scheme for Rough Diamonds, available at www.kimberleyprocess.com.

51 Kimberley Process Certification Scheme (KPCS), available at www.kimberleyprocess.com.

52 KPCS, Section 1, refers to the United Nations General Assembly (UNGA) Resolution 55/56 and other similar UNGA resolutions that may be adopted in the future.

${ }^{53}$ See www.kimberleyprocess.com (as of September 2007).
} 
participation in the scheme as attractive as possible - widespread participation being a prerequisite of the effective self-enforcement of the system. ${ }^{54}$

Although only states are participants in the scheme, the official observers namely, the NGOs Global Witness and Partnership Africa Canada, as well as the World Diamond Council (WDC) as the industry representative (representing jewelers, traders, and manufacturers) - play important roles. The KPCS has three specialized working groups, on monitoring (WGM), statistics, and diamond expertise, respectively. The observers are actively involved in the monitoring group, due to their administrative tasks, and they also partially finance the activities of the WGM (PARTNERSHIP AFRICA CANADA [2006, p. 8]). The peer review system consists essentially of the following components: annual reporting by each participating state, which is not publicized; review visits; and review missions. It is governed by the provisions of an administrative decision. ${ }^{55}$ Furthermore, there is a checklist for review visits from 2007, which recommends that review teams, consisting of participant countries as well as the official observers, should typically examine physical evidence of KPCS compliance through visits to the designated KP Authority, Departments of Minerals and/or Mines, and customs, law enforcement, and related agencies; and through examination of KPCS processes. Teams may also meet with companies and other entities in the diamond sector and with representatives of local civil society, and may visit mines in producer countries. They issue recommendations.

In case a country does not comply with the KPCS, it may be expelled from the scheme. The only country so far to be expelled was the Republic of Congo (Brazzaville), which had been admitted to the scheme in 2003. It has no active diamond mining industry or diamond imports, but was suddenly exporting huge numbers of diamonds. The decision to remove the ROC was based on the findings of a review mission sent by the Kimberley Process to the ROC in May 2004 to assess its compliance with the certification scheme. Led by the South African government, the mission found that the ROC's controls were inadequate, poorly enforced, and therefore unable to prevent conflict diamonds from entering the legitimate diamond trade. ${ }^{56}$ The ROC was readmitted to the Kimberley Process after scrutiny in 2007. Ghana was on the verge of being expelled due to unaccounted smuggling from Côte d'Ivoire (where the government had placed an export ban on diamonds); it is now working to improve controls. ${ }^{57}$

Through a game-theoretic lens, the underlying problem structure for dealing with conflict diamonds is a PD game. Every market participant has an interest in defecting by being able to sell conflict diamonds (if it is an exporting state that trades or mines conflict diamonds) or to buy diamonds at a lower price (if it is a diamond industry). But the Kimberley Process creates a situation where in order for any state or diamond industry to participate in the international diamond trade,

${ }^{54}$ See generally, for the trade-off between participation and compliance, HELFER [2008]; for the KPCS, see CURTIS [2007, p. 11].

${ }_{55}$ Available at www.kimberleyprocess.com.

${ }^{56}$ Global Witness News Release on ROC; see www.kimberleyprocess.com.

${ }^{57}$ See the report of the Kimberley Process review mission by the EU to Ghana, IP/07/418 (27 March 2007), at http://www.europa-euun.org/articles/en/article_6899_en.htm. 
it must adhere to the Kimberley Process. The market is restructured as a club good through the KPCS, thereby making use of the network-externalities rationale. As almost $100 \%$ of the diamond trade is conducted between Kimberley members, and those members, including all the big importing states, admit only certified diamonds, being shut out of the market essentially means that no nonmember can engage in trade. Neither the states nor the industries have an interest in that. This constellation leads to an effective self-enforcing equilibrium. Furthermore, the role of NGOs is considerable. Not only were they the ones that brought the problem to public notice, thus endangering the end market for the high-profityielding jewel diamonds (as opposed to industrial diamonds), but they are also very active in monitoring. By influencing the "world court of public opinion" and by targeting the audience of consumers with deep pockets, they created sharp incentives for the industry to participate in the first place. ${ }^{58}$

The WDC has added teeth to the KPCS by closing the loophole for polished diamonds. It could do so because the diamond industry is a closely knit network, which is very much based on the idea of club goods. ${ }^{59}$ Developed by the International Diamond Manufacturers Association (IDMA) and the World Federation of Diamond Bourses (WFDB) under the auspices of the WDC, a system of warranties for diamonds has been created that has been endorsed by all KPCS participants. Under this system, all buyers and sellers of both rough and polished diamonds must make an affirmative statement on all invoices that the diamonds are purchased from legitimate sources. The following principles of selfregulation were endorsed: to trade only with companies that include warranty declarations on their invoices; not to buy diamonds from suspect sources or unknown suppliers, or that originate in countries that have not implemented the Kimberley Process Certification Scheme; not to buy diamonds from any sources that, after a legally binding due-process system, have been found to have violated government regulations restricting the trade in conflict diamonds; not to buy diamonds in or from any region that is subject to an advisory statement by a governmental authority indicating that conflict diamonds are emanating from or available for sale in that region, unless the diamonds have been exported from that region in compliance with the KPCS; not knowingly to buy or sell or assist others to buy or sell conflict diamonds; and to ensure that all company employees that buy or sell diamonds within the diamond trade are well informed regarding trade resolutions and government regulations restricting the trade in conflict diamonds. ${ }^{60}$ The principles are to be monitored by the firms' auditors. Failure to abide by these principles exposes the member to expulsion from industry organizations.

${ }^{58}$ See, more extensively, also on the network of the diamond industry and traders, FELDMAN [2003, pp. 842f.].

${ }^{59}$ Seminally, BERNSTEIN [1992].

${ }^{60}$ See the description in a letter from the World Diamond Council to its members of November 19, 2002, http://www.worlddiamondcouncil.com/press/ wdc\%20letter\%20111902.html 
Nevertheless, NGOs keep criticizing the self-regulatory system for not being effective. ${ }^{61}$ But it has the advantage that the market actors involved have an active interest in monitoring the gems, for they might be unsure whether the next market actor in line might report on them and thereby get them punished. The system thereby creates incentives for punishing defectors, since nonpunishers are punished themselves. Therefore, the market mechanism works directly in this case - either through the price mechanism or through reputational sanctions among the market players (see BERNSTEIN [1992]).

It should be noticed that the system works in conjunction with the UN and the international trading system, the former relying now on the KPCS in that sanctions against a civil-war country are only ended if the country becomes a member of the KPCS. ${ }^{62}$ The WTO issued a waiver in 2003 in order to create legal security for the participating members that the KPCS was WTO-conforming. ${ }^{63}$ Though the Kimberley Process started with UN sanctions, by now the KPCS serves as their replacement and also validates legitimate conflict-free diamond trade (see CURTIS [2007, p. 27]). It should also be noted that the system works more effectively than the UN Security Council resolutions did (see FELDMAN [2003, p. 845]).

\section{Conclusion and Outlook}

The attempt in this paper has been to draw attention to private actors and market mechanisms in the enforcement of PIL. For methodological reasons, most scholars in international law and economics confine their analysis to states only. This carries the danger that important mechanisms for making PIL effective will be overlooked. Whereas the two-level game of lawmaking procedures is well acknowledged in the scholarship, the two-level game in the second stage, the compliance decision, has not been extensively analyzed. Although, in my view, private actors and market mechanisms do not have the same importance in effectuating PIL in all issue areas, in those areas where private market actors' interests are affected by PIL, whether as private persons or as businesses, their role should be taken into account when reviewing mechanisms for effectuating PIL.

Giving private actors a direct course of action against states is one step in generating compliance. It helps to foster compliance by strengthening the reputational sanction mechanism as international court or tribunal (or committee)

61 See the survey conducted by Amnesty International and Global Witness, http://www.amnesty.org/es/library/asset/POL34/008/2004/en/POL340082004en.html.

${ }^{62}$ See UN/SC/RES/1731, 20 December 2006, and UN/SC/RES/1753, 27 April 2007, on Liberia.

63 WTO Council for Trade in Goods, Waiver Concerning Kimberley Process Certification Scheme for Rough Diamonds: Communication, G/C/W/432/Rev.1 (24 February 2003). For the original waiver, see WTO Council for Trade in Goods, Kimberley Process Certification Scheme for Rough Diamonds - Request for a Waiver, G/C/W/431 (12 November 2002). For discussion of the KPCS in the context of WTO law, see PAUWELYN [2003], SCHEFER [2005], PRICE [2003]. 
decisions generate information. This also holds for nonmarket actors in humanrights law, although the compliance problem may persists in the implementation phase. Nevertheless, litigation is one contribution to using the reputational mechanism in PIL. In international investment law, a tribunal's decision is usually complied with, as noncompliance leads to direct sanctioning by market forces in the postlitigation phase. If bilateral investment treaties are one of the means for attracting capital, ${ }^{64}$ noncompliance with a decision will send a strong signal to potential investors that the country is not protecting and not willing to protect investors' property rights. Thus, private actors play an important role not only in bringing the case in the first place, but also in changing the payoffs in the second stage: the implementation of a ruling.

In issue areas where private actors have no rights and no jus standi but an interest in the litigation, as in the WTO, providing a formal venue for complaints on the national plane might ease the second-order enforcement problem, at least in the first stage (the bringing of a complaint). Thereby, directly affected interests have an influence on the enforcement of PIL.

In constellations without international adjudicatory mechanisms, dealing with issue areas of PIL that ultimately target private market actors, market mechanisms can be used for greater effectiveness. If there is an enforcement system that allows for making use of the incentive structure of network externalities (that is, if it is possible to exclude noncompliant members from the club), then it is in the selfinterest of states to comply with the standards set. That holds even more if the ultimate addressees of the PIL norm (soft or hard) are private actors. Again, we find two possibilities. There may either be a strong lobbying force of private market actors inducing the governments to comply with the standards since otherwise the private actors would not be able to participate in the market (or could do so only with high transaction costs). Or private actors may have a direct role in monitoring compliance of states. Again, those can be NGOs or members of the industries directly concerned. One prerequisite for this kind of system is, first, that it must be possible to create network externalities through international regulation. This is the case if the markets are global and nonparticipation in the market essentially shuts down businesses (as is the case in financial markets or the diamond market). Second, noncompliance needs to be well monitored, because a PD game is played by private actors (and states): Defection, if not detected, would be the preferred option. In order to change payoffs, the costs for noncompliance need to be set high. By (temporary) exclusion, states (and private actors) are retaliating against the violating state.

The lesson learned from the Kimberley Process is that in order to effectuate international sanctions, the system cannot stop short in the black-box state and only impose obligations on states - as it did when only UN sanctions were issued. Rather, it needs to permeate the network of all actors involved, that is, the market forces. In order to create an incentive-compatible system for the market participants, potential (reputational) sanctions in the form of losing market shares through consumer boycotts are necessary. Two prerequisites are needed: first, the sanctions need to target an end-consumer market. Second, there needs to be

\footnotetext{
${ }^{64}$ GUZMAN [1998]; SIMMONS, ELKINS, AND GUZMAN [2008].
} 
transparency and publicity, which can be created by NGOs as independent monitors. If the market targets end consumers, information through monitoring (and thus reputation) can be enhanced by the potential loss of markets if there are moral issues involved. This holds true not only for conflict diamonds but also for the whole discussion on corporate social responsibility. Involvement of industry and NGOs can generate information and thus augment reputation costs considerably.

Those mechanisms are not confined to PIL only. Rather, they can also come into play when states export their regulation. Unilateral sanctions against states that involve private industry, such as prohibiting banks of one's own jurisdiction from doing business with banks that continue to do business with the sanctioned state, can be very effective. Equally, setting certain protective standards, e.g., in food or chemicals regulation, can lead to a de facto export of regulations if the standard-setting jurisdiction has a market that is sufficiently important. To my knowledge, those mechanisms have not yet been analyzed with rational-choice tools, but research in this area seems promising.

\section{References}

Abbott, K. O., R. Keohane, A. Moravcsik, A.-M. Slaughter, And D. SNidal [2000], “The Concept of Legalization,” International Organization, 54, 401-419.

AввOTT, K. W., AND D. SNIDAL [2000], "Hard and Soft Law in International Governance,” International Organization, 54, 421-456.

-- [2001], “' International 'Standards' and International Governance,” Journal of European Public Policy, 8, 345-370.

Amnesty InTERnAtional [2006], "Kimberley Process: An Amnesty International Position Paper. Recommendations to the Kimberley Process (KP) Participants in Order to Effectively Strengthen the Kimberley Process Certification Scheme (KPCS)," http://www.amnestyusa.org/document.php?lang=e\&id=ENGPOL300242006 (last visited Oct. 17, 2008).

BAudenbacher, C., AND E. BuseK (eds.) [2008], The Role of International Courts, German Law Publishers: Germany.

BeRnSTEIN, L. [1992], "Opting out of the Legal System: Extralegal Contractual Relations in the Diamond Industry," Journal of Legal Studies, 21, 115-158.

Besen, S. M., AND J. FARRELL [1994], "Choosing How to Compete: Strategies and Tactics in Standardization," Journal of Economic Perspectives, 8, 117-131.

BogDANDY, A. von [2006], “Constitutionalism in International Law," Harvard International Law Journal, 47, 223-242.

BronCKers, M. [2008], "Private Appeals to WTO Law: An Update,” pp. 117-137 in: C. Baudenbacher and E. Busek, The Role of International Courts, German Law Publishers: Germany.

-- AND N. MCNeLiS [2001], "The EU Trade Barriers Regulation Comes of Age," Journal of World Trade, 35, pp. 427-482.

BuCHANAN, J. M. [1965], “An Economic Theory of Clubs,” Economica, 32, 1-14.

CARlsnaes, W., T. RisSE, AND B. A. Simmons (eds.) [2002], Handbook of International Relations, SAGE: London.

Chayes, A., AND A. HANDler Chayes [1993], “On Compliance,” International Organization, 47, 175-205. 
CURTIS, K. [2007], "But Is It Law? An Analysis on the Legal Nature of the Kimberley Process Certification Scheme on Conflict Diamonds and Its Treatment of Non-State Actors," The American University: International Law Review, http:// works.bepress.com/cgi/viewcontent.cgi?article $=1000 \&$ context=kimberly_curtis.

DobBin, F., B. Simmons, AND G. GARRETT [2007], “The Global Diffusion of Public Policies: Social Construction, Coercion, Competition, or Learning?” Annual Review of Sociology, 33, 21.21-21.24.

DOlZer, R., AND C. SCHREUER [2008], Principles of International Investment Law, Oxford University Press: Oxford.

Downs, G. W., AND M. A. JonEs [2002], "Reputation, Compliance, and International Law,” Journal of Legal Studies, 31, 95-114.

DOYLE, T. [2002], "Cleaning up Anti-Money Laundering Strategies: Current FATF Tactics Needlessly Violate International Law,” Houston Journal of International Law, 24, 279-313.

FASSBENDER, B. [1998], "The United Nations Charter as Constitution of the International Community,” Columbia Journal of Transnational Law, 36, 529-619.

FATF [2007], "Annual Review of Non-Cooperative Countries and Territories 20062007: Eighth NCCT Review,” http://www.fatf-gafi.org/dataoecd/14/11/39552632.pdf. (last visited Oct. 17, 2008).

- - [2008], "Methodology for Assessing Compliance with the FATF 40 Recommendations and the FATF 9 Special Recommendations," http://www.fatf-gafi.org/dataoecd/16/54/40339628.pdf. (last visited Oct. 17, 2008).

FELDMAN, D. L. [2003], "Conflict Diamonds, International Trade Regulation, and the Nature of the Law," University of Pennsylvania Journal of International Economic Law, 24, 835-874.

FroweIN, J. A. [2000], “Konstitutionalisierung des Völkerrechts,” pp. 427-447 in: K. Dicke, Völkerrecht und internationales Privatrecht in einem sich globalisierenden internationalen System, Müller: Heidelberg.

GLOBAL WiTNESS [2005], "Making It Work: Why the Kimberley Process Must Do More to Stop Conflict Diamonds," http://www.globalwitness.org/media_library_detail.php/ 407/en/making_it_work_why_the_kimberley_process_must_do_m (last visited Oct. 17, 2008).

GoldSMith, J. L., AND E. A. Posner [2005], The Limits of International Law, Oxford University Press: Oxford.

GuzMAn, A. [2008], How International Law Works: A Rational Choice Theory, Oxford University Press: Oxford.

GUZMAN, A. T. [2002], “A Compliance-Based Theory of International Law,” California Law Review, 90, 1823-1887.

- - [1998], "Why LDCs Sign Treaties that Hurt Them: Explaining the Popularity of Bilateral Investment Treaties," Virginia Journal of International Law, 38, 639-688.

HELFER, L. R. [2008], "Participation, Compliance, and Nonconsensual International Lawmaking,” Illinois Law Review, 2008, 71-126.

JHERING, R. von [1880], Der Kampf um's Recht, Manz: Wien.

KATZ, M. L., AND C. SHAPIRO [1985], "Network Externalities, Competition, and Compatibility,” American Economic Review, 75, 424-440.

- - AND - - [1994], "Systems Competition and Network Effects." Journal of Economic Perspectives, 8, 93-115.

KOH, H. H. [1997a], “How Is International Human Rights Law Enforced?” Indiana Law Journal, 74, 1397-1417.

- - [1997b], “Why Do Nations Obey International Law?” Yale Law Journal, 106, 25992659. 
LESTER, S., AND B. MERCURIO [2008], World Trade Law, Hart: Oxford.

LEVIT, J. K. [2007], "Bottom-Up International Lawmaking: Reflections on the New Haven School of International Law,” Yale Journal of International Law, 32, 393-420.

LiEBOwITZ, S. J., AND S. E. MARGOLIS [1994], "Network Externality: An Uncommon Tragedy,” Journal of Economic Perspectives, 8, 133-150.

MCADAMS, R. H., AND J. NADLER [2008], "Coordinating in the Shadow of the Law: Two Contextualized Tests of the Focal Point Theory of Legal Compliance," University of Chicago Law \& Economics, Olin Working Paper No. 406, http://ssrn.com/ abstract $=1016488$.

MCCuBBins, M. D., AND T. SCHWARTZ [1984], "Congressional Oversight Overlooked: Police Patrols versus Fire Alarms,” American Journal of Political Science, 28, 165179.

MORAVCSIK, A. [1997], "Taking Preferences Seriously: A Liberal Theory of International Politics,” International Organization, 51, 516-553.

Ostrom, E. [2000], "Collective Action and the Evolution of Social Norms.” Journal of Economic Perspectives, 14, 137-158.

PARISI, F., AND N. GHEI [2003], "The Role of Reciprocity in International Law,” Cornell International Law Journal, 36, 93-123.

PARTNERSHIP AFRICA CANADA [2006], "Killing Kimberley? Conflict Diamonds and Paper Tigers,” http://www.pacweb.org/e/images/stories/documents/ 15_killingkimberley_eng.pdf.

PATTBERG, P. [2005], "The Institutionalization of Private Governance: How Business and Nonprofit Organizations Agree on Transnational Rules," Governance: An International Journal of Policy, Administration, and Institutions, 18, 589-610.

PAUWELYN, J. [2003], "WTO Compassion or Superiority Complex? What to Make of the WTO Waiver for 'Conflict Diamonds'," Michigan Journal of International Law, 24, 1177-1207.

Peters, A. [2006], "Compensatory Constitutionalism: The Function and Potential of Fundamental International Norms and Structures,” Leiden Journal of International Law, 19, 579-610.

PricE, T. M. [2003], “The Kimberley Process: Conflict Diamonds, WTO Obligations, and the Universality Debate,” Minnesota Journal of Global Trade, 12, 1-69.

PutnAM, R. D. [1988], "Diplomacy and Domestic Politics: The Logic of Two-Level Games,” International Organization, 42, 427-460.

SchefER, K. N. [2005], "Stopping Trade in Conflict Diamonds: Exploring the Trade and Human Rights Interface with the WTO Waiver for the Kimberley Process,” pp. 391450 in: T. Cottier, J. Pauwelyn, and E. Bürgi Bonanomi, Human Rights and International Trade, Oxford University Press: Oxford.

SCOTT, R. E., AND P. B. STEPHAN [2006], The Limits of Leviathan: Contract Theory and the Enforcement of International Law, Cambridge University Press: Cambridge.

ShAfFer, G. C. [2003], Defending Interests: Public-Private Partnerships in WTO Litigation, Brookings Institution Press: Washington D.C.

Simmons, B., Z. ELKINS, AND A. GUZMAN [2008], "Competing for Capital: The Diffusion of Bilateral Investment Treaties, 1960-2000,” Illinois Law Review, 2008, 265-304.

Simmons, B. A. [2001], "The International Politics of Harmonization: The Case of Capital Market Regulation,” International Organization, 55, 589-620.

Slaughter, A.-M. [2004], A New World Order, Princeton University Press: Princeton.

Sloss, D., AND D. JinKS (eds.) [2009], The Role of Domestic Courts in Treaty Enforcement, Cambridge University Press: Cambridge. 
SoNG, J. [2007], "A Comparative Study on the Trade Barriers Regulation and the Foreign Trade Barriers Investigation Rules,” Journal of World Trade, 41, 799-831.

STESSENS, G. [2001], “The FATF 'Black List' of Non-Cooperative Countries or Territories," Leiden Journal of International Law, 14, 199-208.

SYKeS, A. O. N. [2005], "Public vs. Private Enforcement of International Economic Law: Of Standing and Remedy," Journal of Legal Studies, 34, 631-666.

TAMM, I. J. [2004], "Dangerous Appetites: Human Rights Activism and Conflict Commodities,” Human Rights Quarterly, 26, 687-704.

VAN AAKEN, A. [2005], "Making International Human Rights Protection More Effective: A Rational-Choice Approach to the Effectiveness of Ius Standi Provisions,” Preprint 2005/16 of the Max Planck Institute for Research on Collective Goods.

- - [2004], "Verstärkte Kontrolle Transnationaler Finanzströme nach dem 11. September 2001,” pp. 133-164 in: M. Bungenberg and K. Meessen, Internationales Wirtschaftsrecht im Schatten des 11. September 2001, Boorberg: Stuttgart.

WALTER, C. [2001], “Constitutionalizing (Inter)National Governance," German Yearbook of International Law, 44, 170-201.

WET, E. D. [2006], “The International Constitutional Order," International \& Comparative Law Quarterly, 55, 51-76.

Anne van Aaken

Max-Schmidheiny Tenure Track Professor

of Law and Economics, Public Law,

International and European Law

University of St. Gallen

Guisanstrasse 36

9010 St. Gallen

Switzerland

E-mail:

anne.vanaaken@unisg.ch 